\title{
Beata Bielska, „Magisterkę kupię”. Sprzedawanie i kupowanie prac dyplomowych jako element studenckiej kultury nieuczciwości, Wydawnictwo Naukowe Uniwersytetu Mikołaja Kopernika, Toruń 2015, ss. 248
}

Zjawisko umasowienia dostępności wyższego wykształcenia przez długi czas traktowane było jako niewątpliwy sukces polskiej transformacji. Chłonny, potrzebujący nowych kompetencji rynek pracy otwierał przed osobami legitymującymi się dyplomami uczelni wyższych perspektywy atrakcyjnego, prestiżowego, dobrze wynagradzanego zatrudnienia. Szanse takie dawały zarówno powstające w kraju oddziały zachodnich korporacji, dynamicznie rozwijający się rodzimy mały biznes, jak i modernizujące się w związku z przemianami ustrojowymi instytucje publiczne. W wyższym wykształceniu upatrywano także ratunku przed bezrobociem, które stało się dotkliwym fundamentem transformacyjnej traumy. Według danych GUS u progu lat 90. XX w. na polskich uczelniach studiowało niewiele ponad 400 tysięcy osób. W roku akademickim 1997/1998 liczba studentów przekroczyła milion, zaś kolejne osiem lat później uległa niemalże podwojeniu (1,95 mln w roku akademickim 2005/2006). Był to jednocześnie moment nasycenia, poprzedzający trwającą do chwili obecnej tendencję spadkową, związaną także z konsekwencjami niżu demograficznego. Współczynnik skolaryzacji netto z notowanej u początków przemian transformacyjnych (rok akademicki 1990/1991) wartości 13\% wzrósł w ciągu dekady do 40\%, a w roku 2007/2008 przekroczył 50\% (za Bielska, 2015, s. 34-36). Wraz z rosnącym popytem na wyższe wykształ-

1 Magdalena Bergmann, Instytut Nauk Społecznych, Wyższa Szkoła Gospodarki w Bydgoszczy, magdalena.bergmann@byd.pl. 
cenie pojawiła się także zwiększona podaż. Uczelnie publiczne poszerzyły ofertę edukacyjną, zarówno zwiększając liczbę miejsc na studiach, szczególnie w trybie niestacjonarnym, jak i tworząc nowe kierunki i specjalności). Powstał także liczący ponad 300 podmiotów sektor uczelni niepublicznych, tworzonych również poza dużymi ośrodkami akademickimi.

Ilościowy boom na polskich uczelniach przyniósł jednakże i zjawiska o charakterze problematycznym. Społeczność akademicka zaczęła dostrzegać niedogodności, czy wręcz dysfunkcje związane z żywiołowym rozwojem szkół wyższych i dostępności dyplomu: dużą liczbę studentów przypadających na pracownika naukowo-dydaktycznego, zmieniającą relację „mistrz-uczeń” w umasowiony transfer wiedzy, wieloetatowość wykładowców (zwłaszcza przy korzystaniu z potencjału kadrowego uczelni publicznych przez ich niepublicznych konkurentów), słabnące mechanizmy selekcyjne w rekrutacji na studia (przy jednoczesnym dążeniu do przyjmowania możliwie dużej liczby kandydatów ze względów finansowych), wreszcie studencką nierzetelność i nieuczciwość, przejawiającą się ściąganiem, plagiatowaniem prac bądź ich kupowaniem (zob. także Krzewińska, Przybyłowska, 2012). Zjawiska te w konsekwencji zaczęły przekładać się na obniżenie jakości nauczania, a także dewaluację wartości wyższego wykształcenia, zmieniającego się w społecznej percepcji w rządzącą się prawami rynku kolejną usługę - w tym przypadku edukacyjną. Konieczność krytycznego przyjrzenia się mechanizmom występującym w szkolnictwie wyższym wymusiła także zmieniająca się z końcem lat 90. sytuacja na rynku pracy - spowolnienie młodej gospodarki rynkowej i wzrost bezrobocia (także wśród najlepiej wykwalifikowanej siły roboczej). W jakim stopniu kształcenie odpowiada na potrzeby pracodawców? Jak wyższe wykształcenie przekłada się na finansowe profity z pracy? Czy nadal można mówić o nim jako o znaczącym kanale awansu społecznego?

Takie właśnie - przytoczone powyżej w zarysie - kontekstualne tło analizowanego problemu prezentuje w swej książce Beata Bielska, absolwentka, a obecnie doktorantka Instytutu Socjologii Uniwersytetu Mikołaja Kopernika. Praca jest rezultatem zainteresowań badawczych autorki eksplorowanych nie tylko na etapie pracy magisterskiej, ale i jej wcześniejszej działalności w funkcjonującym w strukturze IS UMK Zespole Realizacji Badań Pryzmat, w ramach którego współtworzyła m.in. raport z badań nad zjawiskami ściągania i plagiatowania na toruńskim uniwersytecie (Bielska, Hoffman, 2013). Książka składa się z pięciu zasadniczych rozdziałów, którym towarzyszą także przedmowa recenzenta, wstęp i zakończenie oraz aneks zawierający m.in. wzory narzędzi wykorzystanych w badaniach empirycznych. Zasygnalizowane w tytule pracy pojęcie „studenckiej kultury nieuczciwości” autorka osadziła we wspomnianych wyżej przemianach 
makrospołecznych zachodzących w Polsce po 1989 r., w tym instytucjonalnych, obejmujących sektor szkolnictwa wyższego oraz zdefiniowała jako „utrwalone i przekazywane wartości, normy, postawy i wzory zachowań studentów wiążące się ze stałym, powszechnym przyzwoleniem na łamanie norm oficjalnych dotyczących pełnienia roli społecznej studenta/studentki” (Bielska, 2015, s. 19). Zdaniem autorki takie postawy i zachowania studentów polskich uczelni wykazują analogię do innych przejawów nierzetelności i nieuczciwości występujących w społeczeństwie. Mogą bowiem stanowić kontynuację uczniowskiej kultury ściągania, być przedbiegiem do oszukiwania pracodawcy w przyszłości bądź odbiciem przyzwolenia na rozmaite naruszenia dóbr publicznych (niepłacenie podatków, jazdę „na gapę” komunikacją miejską, wyłudzanie zasiłków).

Jak konstatuje Bielska, odwołując się jednocześnie do klasycznych kategorii pojęciowych socjologii, nadużycia popełniane na drodze do ukończenia studiów mogą być rozpatrywane jako wskaźniki anomii w ujęciu Roberta K. Mertona silnej rozbieżności pomiędzy normami i celami kulturowymi a możliwościami ich realizacji. Mertonowskie podejście do anomii wydaje się zresztą dominującą perspektywą teoretyczno-analityczną w pracy Beaty Bielskiej. Społecznie akceptowany, a nawet będący przedmiotem presji (rodzinnej, rówieśniczej) cel kulturowy, jakim jest zdobycie wyższego wykształcenia, zaczął napotykać we współczesnej Polsce trudności w zrealizowaniu go powszechnie akceptowanymi środkami, tj. rzetelną, samodzielną pracą. Pojawiają się inne (w terminologii Mertona - dewiacyjne/innowacyjne), być może społecznie potępiane, niemniej jednak ośmielające działające jednostki sposoby uzyskania upragnionego dyplomu: ściąganie na egzaminach, plagiatowanie prac czy ich kupowanie od świadczących odpowiednie usługi osób bądź firm. Autorka korzysta także z innych perspektyw teoretycznych, ukazując problem handlu pracami dyplomowymi w świetle teorii racjonalnego wyboru. Uzyskanie dyplomu na podstawie kupionej pracy licencjackiej czy magisterskiej może być dogodną dla studenta strategią maksymalizacji wygranej lub unikania przegranej, gdy praca taka daje szansę na uzyskanie oceny lepszej niż w przypadku samodzielnie, lecz niedbale napisanej rozprawy. Motywacje studentów maksymalizujących jednostkowe korzyści poprzez korzystanie z kupionych prac dyplomowych mogą być jednak szkodliwe w skali makrospołecznej. Autorka porównuje je do znanych z teorii racjonalnego wyboru zachowań „samotnego rybaka” bądź „pasażera na gapę” - korzystając ze wspólnego dobra, jakim jest wyższe wykształcenie w sposób nieuprawniony, niebiorący pod uwagę dążeń innych użytkowników i niewnoszący własnego wysiłku, nieuczciwi studenci doprowadzają do społecznej i ekonomicznej dewaluacji wartości dyplomu. 
Najważniejszym punktem empirycznej warstwy książki jest raport ze zrealizowanych przez autorkę badań jakościowych środowiska osób i firm zajmujących się pisaniem pracy dyplomowych na zlecenie. Warto jednak zatrzymać uwagę na jednym z wcześniejszych rozdziałów, przybliżającym terminologię oraz prawno-formalne aspekty problemu handlu pracami, dostarcza on bowiem ważnej wiedzy o tym częściowo niejawnym i nieczęsto w Polsce badanym zjawisku. Bielska zauważa podobieństwa pomiędzy sprzedażą-kupnem prac dyplomowych a naukowym plagiatorstwem - w obu przypadkach dochodzi bowiem do przedstawienia jako własnego tekstu napisanego w całości lub znacznych częściach przez inną osobę, a tym samym pogwałcenia praw autorskich. Inna zbieżność pomiędzy zjawiskami przejawia się w tym, iż tworzone przez piszących prace mogą być oferowane potencjalnym odbiorcom wielokrotnie, w niezmienionej lub nieznacznie zmodyfikowanej wersji. Zorganizowane grupy piszących ogłaszają ponadto skupowanie już obronionych prac magisterskich. Tworzy to potencjalnie nieprzewidzianą dla studenta-klienta, a brzemienną w skutkach prawnych sytuację, w której zakupiona praca dyplomowa może zostać uznana za plagiat. Odpowiedzialność zgodnie z przepisami Kodeksu Karnego ponosi bowiem osoba, która przedkładając cudzą pracę do obrony jako swoją, poświadcza nieprawdę. Jak zauważa autorka, rynek autorów prac dyplomowych cechuje w tym punkcie zapobiegliwość granicząca z cynizmem: „(...) bardzo istotny jest sposób ogłaszania się zleceniobiorcy (osoby piszącej, sprzedającej pracę). W wielu przypadkach, zwłaszcza gdy mówimy o firmach profesjonalnie zajmujących się przygotowywaniem prac na zlecenie, na stronach internetowych pojawia się informacja, że powstające utwory są jedynie pracami pomocniczymi czy wzorcowymi, a osoba czy firma przygotowująca pracę nie ponosi odpowiedzialności za jej wykorzystanie” (ibidem, s. 92-93). Można uznać to za swoistą kreację rzeczywistości społecznej ze specyficznym dyskursem przekonującym, że jeśli dochodzi do złamania norm społecznych i prawnych, dzieje się tak wyłącznie z winy osoby korzystającej, nie zaś świadczącej usługę. W tym rozdziale autorka zawarła także krytyczne uwagi pod adresem funkcjonujących w Polsce systemów antyplagiatowych jako niespełniających swego zadania - rozdrobnionych, posługujących się różnymi, nie zawsze kompatybilnymi narzędziami analizy, czy wręcz, paradoksalnie, przysługujących się rozwojowi procederu sprzedaży i kupna prac: „Warto zwrócić uwagę, że firmy i osoby piszące prace są klientami systemu antyplagiatowego. Tym samym system, który ma chronić przed plagiatami w oryginalnych pracach dyplomowych, jest wykorzystywany do celów sprzecznych z ideą uczciwego przedstawiania własnej pracy dyplomowej” (ibidem, s. 195).

Wspomniane już wcześniej badania środowiska osób, grup i firm zajmujących się pisaniem prac dyplomowych na zlecenie Bielska przeprowadziła, posługując się 
różnorodnym, uwzględniającym nietypowy i trudny grunt empiryczny instrumentarium badań jakościowych: wywiadami swobodnymi przeprowadzonymi zarówno z autorami prac, jak i osobami, które zetknęły się ze zjawiskiem, schematem eksperymentu-prowokacji, polegającym na postawieniu się przez badaczkę w roli osoby zainteresowanej kupnem pracy i wejściu w interakcję z usługodawcą, a także analizą treści stron internetowych firm oferujących prace „na zlecenie”. Autorka zdaje sobie sprawę z dylematów etycznych towarzyszących badaniom niejawnym i prowadzonym w rzeczywistości wirtualnej, a także wykorzystania tzw. brudnych danych, szczegółowo waży argumenty „za” i „przeciw”, a nawiązując do paradygmatu socjologii radykalnej/zaangażowanej (ibidem, s. 140), opowiada się finalnie za wybraną strategią i metodologią z uwagi na demaskatorski, krytyczny i potencjalnie użyteczny społecznie charakter badań. W rozdziale badawczym autorka ukazuje, w jak przemyślany sposób firmy prezentują ofertę i konstruują wizerunek swoich usług w Internecie. Dominuje tu oczywiście wspomniana wcześniej perspektywa kreowania rzeczywistości i neutralizowania negatywnych konotacji zjawiska, w myśl których kupienie pracy dyplomowej nazywane jest skorzystaniem ze „wzoru”, „opracowania”, „pomocy” przy pracy twórczej (ibidem, s. 175-177). W wywiadach dyplomowi „ghostwriterzy” prezentują zgoła odmienny obraz swojej pracy. Są świadomi, iż wykonują usługi, na które zapotrzebowanie związane jest z patologiami systemu szkolnictwa wyższego, a ich cechujący się lenistwem i płytką motywacją klienci traktują wykształcenie jako formalność niezbędną do poruszania się po rynku pracy, nie zaś ścieżkę rozwoju intelektualnego. Niektórzy respondenci badaczki wprost winią system, utrzymując, że gdyby szkolnictwo wyższe nie było tak umasowione, ich praca nie byłaby potrzebna (ibidem, s. 187). Badania ukazały także zróżnicowane wzorce funkcjonowania branży prac dyplomowych „na zamówienie”, obejmujące osoby indywidualne, nieformalne grupy autorów oraz zarejestrowane firmy piszących specjalizujących się, w pracach z jednego kierunku, jak i oferujących swe usługi na kilku polach, wreszcie zróżnicowany wachlarz usług - od sprzedaży gotowych prac, po produkt częściowy (np. wykonanie jedynie analiz statystycznych), aż po całkowite wyręczenie autora w napisaniu pracy na wskazany przez niego temat. Z wywiadów z osobami oferującymi prace wyłaniają się wreszcie pośrednio (autorce nie udało się bowiem pozyskać do badań kupujących) typy klientów, które Bielska nazwała umownie „przymuszonymi” i „wybierającymi” (ibidem, s. 188) - powodowanymi brakiem czasu i obowiązkami zawodowymi czy rodzinnymi, jak również tymi, których problemem jest brak pracowitości, motywacji i wiary w realne oddziaływanie wykształcenia. Podsumowując wyniki swoich poszukiwań empirycznych, badaczka sformułowała listę rekomendacji dla poprawy sytuacji 
w obszarze przeciwdziałania studenckiej nieuczciwości. Część z nich ma charakter praktycznych wskazówek odnoszących się do organizacji procesu dydaktycznego (m.in. praca w małych grupach, obligatoryjna etapowość pracy nad rozprawą i jej referowanie na seminarium), inne są postulatami głębszej, aksjonormatywnej zmiany, która dla swej skuteczności powinna zajść na poziomie systemowym - np. konsekwentne komunikowanie wyższego wykształcenia jako dobra wspólnego, a nie tylko jednostkowej korzyści, odejście od masowego schematu bezpłatnego kształcenia (ibidem, s. 220-222).

Książka Beaty Bielskiej nie wyczerpała problemu studenckiej nieuczciwości, przejawiającej się w korzystaniu z kupionych prac dyplomowych. Dzieje się tak choćby z powodu - sygnalizowanych zresztą wielokrotnie przez autorkę - trudności w dostępie do badanej rzeczywistości, stanowiącej funkcjonujący półjawnie, zawoalowany, balansujący na krawędzi prawa i obwarowany silnie chronionymi interesami jego uczestników obszar życia społecznego. Niemniej socjolożka bez wątpienia pokazała swoje kompetencje metodologiczne i udowodniła, że umiejętnie posługuje się instrumentarium badań jakościowych, by eksplorować złożoną, ukrytą, wymykającą się oficjalnym mechanizmom i procedurom rzeczywistość. Być może interesującym uzupełnieniem badań nad specyfiką zjawiska (i jednocześnie także inspiracją dla innych badaczy, reprezentujących nie tylko socjologię, ale i np. językoznawstwo czy informację naukową) byłoby oparcie się na jego artefaktach - pochodzących z rynku „mózgów do wynajęcia” pracach dyplomowych i przeprowadzenie ich analiz bibliologicznych, czy też wykonanie studiów przypadków, w których udało się udowodnić posłużenie się zakupioną pracą napisaną przez zleceniobiorcę.

Praca Beaty Bielskiej stanowić będzie dużą wartość poznawczą zarówno dla badaczy społecznych zainteresowanych przemianami szkolnictwa wyższego we współczesnej Polsce, jak i dla poszukujących metodologicznych i warsztatowych inspiracji dla prowadzenia jakościowych badań społecznych, szczególnie zjawisk ukrytych, problematycznych, stwarzających trudności w eksploracji technikami wystandaryzowanymi. Lektura bez wątpienia poszerzy też wiedzę oraz świadomość promotorów prac dyplomowych i osób odpowiedzialnych za jakość kształcenia, niezależnie od reprezentowanej dyscypliny nauki. Wskazuje bowiem, jak dynamicznie rozwija się dzięki informatyzacji i jak wyrafinowanymi metodami posługuje się półjawny rynek usług, które sprzeczne są z etosem samodzielnej pracy naukowej. Odsłania też pośrednio motywacje jednostek, które korzystając z takiego rozwiązania, również sprzeniewierzają się zasadzie akademickiej uczciwości i podtrzymują funkcjonowanie owego rynku. 


\section{Literatura:}

Bielska, B. (2015). „Magisterkę kupię”. Sprzedawanie i kupowanie prac dyplomowych jako element studenckiej kultury nieuczciwości. Toruń: Wydawnictwo Naukowe UMK. Bielska, B., Hoffman, M. (2013). Jak wykiwać system - studencka zaradność czy oszustwo? Raport z badania na temat ściągania i plagiatowania. Pobrane z: http://www.academia. edu/5120451/Beata_Bielska_i_Martyna_Hoffman_Jak_wykiwa\%C4\%87_system_Raport_z_badania_na_temat_\%C5\%9Bci\%C4\%85gania_i_plagiatowania.

Krzewińska, A., Przybyłowska, I. (2012). Patologiczne zachowania studentów związane ze studiowaniem. Normy, Dewiacje i Kontrola Społeczna, 13, s. 313-337. 